and sales between one soft-currency country and another. So far, twenty-four countries have joined in the project. Coupons will be marketed in Great Britain by the British Film Institute, 164 Shaftesbury Avenue, London, W.C.2, which will also be the central body dealing with imports and exports under the scheme. Intending purchasers must satisfy themselves that the particular film they want is educational, scientific or cultural, and also make sure of the availability and price of the film. The British Film Institute will provide the necessary import form and in due course obtain the film, clear it through Customs and hand it over to the purchaser. Where the Institute receives a request from abroad, supported by the appropriate coupons, for the purchase of British films, it will get into contact with the owner and make arrangements for shipment; payment for films purchased in this way will be made by the Institute. No orders for non-British films will be accepted from a foreign purchaser, and films must be supplied to foreign purchasers by outright sale without any contingent payments.

\section{British Jute Trade Research Association: Annual Meeting}

AT the annual general meeting of the British Jute Trade Research Association, held on November 14 in the offices of the Association, Kinnoull Road, Kingsway West, Dundee, the chairman of the Council, Mr. George E. Scott, in moving the adoption of the accounts and annual report for the year ending June 30 , said that a considerable expansion in staff and plant has taken place during the past year. Commenting on the great increase in basic knowledge relative to jute, Mr. Scott said that all sections of the industry are utilizing the facilities made available by the technical inquiry service of the Association, particularly with regard to day-to-day problems; the steady increase in the number of such inquiries illustrates the reliance on the work of the Association. Mr. Scott also referred to the publicity value of the research station to the industry, impressing as it did upon users of jute goods the desire of the industry to do all within its power in the provision of quality products and materials for special purposes. The director of research, Mr. H. Corteen, reviewed the different ways in which the Research Association can be of assistance to its members. In order to hasten the practical application of the results of research conducted in the Association's laboratories and workshops, a series of training schemes are being set up, whereby personnel of member firms can be trained in particular aspects of work. During the day of the meeting, approximately 170 of the supervisory personnel of member firms visited the Association's premises and were shown the various research investigations being carried on, this being the first open day' organized by the Association for that purpose.

\section{$X$ Disease of the Peach}

A virus attacking peach and chokecherry (Prunus virginiana), and rather appropriately known as $\mathrm{X}$ disease, is now of considerable importance in the north-eastern United States. Ernest M. Stoddard (Conn. Agric. Exp. Sta. Bull. 506; pp. 19 ; New Haven, U.S.A. ; May 1947) has investigated methods of spread and possible control of the trouble. The virus is transmitted by budding or grafting, but not by mechanical means; it can spread on chokecherries and from them to peach, but not from peach to peach and, in all probability, not from peach to chokecherry. An obvious method of control is to eliminate choke. cherries from the neighbourhood of peach orchards. It is, however, claimed that the virus is inactivated in diseased living peach buds by soaking such buds in aqueous solutions of chemicals which include various sulphonamides, quinolines, and even calcium chloride. Living peach trees can also be immunized against artificial inoculations of $\mathrm{X}$ disease by watering the soil with various aqueous solutions. Heat treatment of peach buds is also claimed to lower the infectiveness of the virus. It would appear that important issues are raised by this work-so important that, without any disrespect to the author, they merit independent confirmation.

\section{Ceylon Coconut Quarterly}

THE coconut industry is a major industry in Ceylon and almost entirely in the hands of the Ceylonese. Coconut products are the second best exchange earner for the island. In December 1928 an Ordinance to provide for the establishment of a Coconut Research Scheme became law, though its finances were always inadequate. The Ordinance required that the board of the Research Scheme should, by the provision of information, give practical assistance to persons engaged in the industry. Hitherto, it had only been possible to issue advisory leaflets at irregular intervals with an occasional article in the Tropical Agriculturist. But the absence of a regular journal was always felt as a serious omission. The Ceylon Coconut Quarterly has now come into being (1, No. 1, January-March 1950; Lunuwila: Coconut Research Scheme). Messages of welcome are published from the Prime Minister of Ceylon and the Ministers of Agriculture and Lands. the Food and Co-operative Undertakings, and Commerce and Trade. As the Prime Minister points out, neglect in the plantations existed before the Second World War, and during the War cultivation, manuring and replanting were not done. The establishment of nurseries and the dissemination of young seedling plants by the Research Centre has done much to improve crops. It is said that the yields from crops grown from the specially selected nuts and seedlings may yield 5,000 nuts per acre, instead of the average 1,800 from more or less uncultivated plantations. The aim of the Quarterly is to provide information of all kinds on the subject of the industry and to make the information available not only to the larger growers, but also to the smallholders, who form the majority of the coconut producers.

\section{Colonial Service: Recent Appointments}

THE following appointments in the Colonial Service have recently been announced: W. T. Dalgarno (senior agricultural officer, Nigeria), principal farm industries officer, Department of Commerce and Industries, Nigeria; M. W. Gibbon (senior agricultural officer, Nigeria), principal agricultural officer, Nigeria ; A. E. Moss (senior agricultural officer, Gold Coast), assistant director of agriculture (cocoa industry), Gold Coast; R. J. M. Swynnerton (senior agricultural officer, Tanganyika), assistant director of agriculture (field services), Kenya; D. A. Russell (principal, Government Technical School, Takoradi, Gold Coast), chief inspector of education (technical), Nigeria ; J. F. Bates, entomologist, British Guiana; F. A. Carver, agricultural officer, Fiji ; C. R. Dickson, agricultural officer, Gold Coast ; L. Johnson, economic botanist, Trinidad; A. S. MacDonald, agricultural 